\title{
Influence of process conditions on quality of spouted bed dried okara
}

Scafi, G.A.O. ${ }^{\text {a }}$ Lazarin, R.A. ${ }^{\text {; }}$ Kurozawa, L.E. ${ }^{a^{*}}$

${ }^{a}$ School of Food Engineering. University of Campinas, Campinas, Brazil.

*E-mail of the corresponding author: louisek@unicamp.br

\begin{abstract}
This study aimed to evaluate the spouted bed drying of okara with inert particles of polypropylene. A central composite rotatable design was carried out to verify the effect of drying air temperature and air flow on moisture content, techno-functional properties and trypsin inhibitors activity of dried product. Higher temperatures decreased emulsifying properties and trypsin inhibitor activity, probably due to thermal protein denaturation. In order to obtain a dried okara with maximum techno-functional properties and minimum moisture content and trypsin inhibitor activity, the optimal drying conditions were suggested: air temperature of $60^{\circ} \mathrm{C}$ and air flow of $180 \mathrm{~m}^{3} / \mathrm{h}$.
\end{abstract}

Keywords: soy pulp; spouted bed drying; trypsin inhibitor activity; technofunctional properties; optimization 


\section{Introduction}

During the processing of soymilk and tofu, an insoluble residue, also know as okara or soy pulp, is generated. Since the sales volume of soymilk of worldwide reached 13.5 billion liters in $2015^{[1]}$, significant quantities of okara are underutilized as animal feed or discarded, resulting in environmental problems. However, okara can be used for human consumption or as ingredient to increase the functional properties of food products due to its considerable high protein content ${ }^{[2]}$.

Soy proteins play an important role in the food industry due to their nutritive value and ability to improve the functional properties. Okara proteins, whose main fractions are the basic $7 \mathrm{~S}$ globulin and $11 \mathrm{~S}^{[3]}$, presented better emulsion stability and similar emulsion activity than soy protein ${ }^{[4]}$. Moreover, unlike other vegetable proteins, okara proteins have all of the essential amino acids necessary for good health ${ }^{[5]}$. However, okara contains trypsin inhibitor, which have been considered an antinutritional factor of soy consumption by promoting the reduction of protein digestibility ${ }^{[6]}$.

Thus, aiming the use of okara by the food industry, some preservation method must be applied to improve its shelf life, since okara contains high moisture content (75-80\%) and is very perishable. Amongst the several methods employed for preservation, drying is a process in which water activity of food is reduced by removal of moisture by vaporization or sublimation. However, okara is a material difficult to dry, since its wet particles are cohesive. Moreover, the diffusion of internal moisture is slow, resulting in long drying time when it is dried in static dryers ${ }^{[7]}$. These drawbacks can be solved using dynamic dryers, such as spouted bed dryer, and by adding inert particles to the moist and cohesive material.

The objective of the current work is to evaluate the spouted bed drying of okara, analyzing the influence of process parameters on dried product quality.

\section{Materials and Methods}

\subsection{Material}

Soybean (Glycine max (L.) Merr.) cultivar BRS 257, which is lipoxygenase-free, was acquired from SL Alimentos (Mauá da Serra, Brazil). Polypropylene particles were used as inert material. Trypsin and benzoyl-DL-arginine-4-nitroanilide hydrochloride substrate (BAPNA) (Sigma-Aldrich, St. Louis, USA) were used for analysis of the trypsin inhibitors.

\subsection{Preparation of okara}

The okara was obtained from soymilk processing according to Baú and $\operatorname{Ida}^{[8]}$. Soybeans were soaked in water at $1: 3$ ratio (w:w, soybean:water) for $12 \mathrm{~h}$ at $8^{\circ} \mathrm{C}$, drained and homogenized with distilled water at 1:8 ratio (w:w, soybean:water) using an industrial blender (model LB25 , Skymsen $^{\circledR}$, Brusque, Brazil) for 5 min. The mixture was filtered, obtaining the insoluble 
fraction okara. The moisture content of okara was $75.2 \pm 0.1 \%$ (wet basis). Ash, lipid and protein contents of okara, obtained by $\mathrm{AOAC}^{[9]}$, were in dry basis $3.5 \pm 1.0 \%, 13.9 \pm 0.5 \%$ and $35.1 \pm 1.0 \%$, respectively. Carbohydrate content (dry basis), calculated by difference, was $47.4 \pm 1.5 \%$. Samples were stored at $-18^{\circ} \mathrm{C}$ and thawed according to the quantity required for spouted bed drying.

\subsection{Spouted bed drying of okara}

The drying of okara was carried out in a spouted bed dryer (model FBDG3, O'Hara Technologies, Ontario, Canada). The dryer consists of a conical base with an inferior diameter of $85 \mathrm{~mm}$, superior diameter of $393 \mathrm{~mm}$, height of $400 \mathrm{~mm}$ and inlet orifice diameter of $48 \mathrm{~mm}$. The upper part of conical base consists of a cylindrical column.

Previous to drying of okara, the spouted bed dryer was put into operation with $1 \mathrm{~kg}$ of inert particles. Heated air was blowed at the inferior part of conical base at different flow rates (Table 1). After the permanent regime was reached, $500 \mathrm{~g}$ of moist okara were introduced into the dryer. For all experiments, total drying time was $30 \mathrm{~min}$. The load of inert particles, mass of okara:mass of particle inert ratio and drying time were determined in preliminar tests. At the end of drying, dried okara was separated from the inert particles by sieve with $2 \mathrm{~mm}$ opening.

A central composite rotatable design was carried out to verify the effect of drying air temperature $\left(40\right.$ to $\left.80^{\circ} \mathrm{C}\right)$ and air flow $\left(140\right.$ to $\left.180 \mathrm{~m}^{3} / \mathrm{h}\right)$ on moisture content, technofunctional properties (emulsifying capacity, emulsion stability and water absorption index) and trypsin inhibitors activity of dried product. Experimental data were fitted to Equation $(1)^{[10]}$.

$$
y=b_{0}+b_{1} x_{1}+b_{2} x_{2}+b_{11} x_{1}^{2}+b_{22} x_{2}^{2}+b_{12} x_{1} x_{2}
$$

Where: $y$ is the response, $b_{0}, b_{1}$ and $b_{2}, b_{11}$ and $b_{22}$, and $b_{12}$ are the constant, linear, quadratic and cross-product regression coefficients, respectively, and $\mathrm{x}_{1}$ and $\mathrm{x}_{2}$ represent the coded values of the $\mathrm{T}_{\text {in }}$ and $\mathrm{W}$ variables, respectively.

Regression coefficients of the predictive models were obtained by the Protimiza software (http://experimental-design.protimiza.com.br). Coefficients within a confidence level above $90 \%$ were considered significant $(\mathrm{p}<0.1)$. Non-significant terms were eliminated, and the model was tested for adequacy by analysis of variance (Anova), coefficient of determination $\left(\mathrm{R}^{2}\right)$ and F-test. 
Table 1. Screening design for spouted bed drying of okara, regression coefficients and Anova

\begin{tabular}{|c|c|c|c|c|c|c|c|}
\hline \multirow[t]{2}{*}{ Assay } & \multicolumn{2}{|c|}{$\begin{array}{c}\text { Independent } \\
\text { variables }\end{array}$} & \multicolumn{5}{|c|}{ Dependent variables } \\
\hline & $\mathbf{T}_{\text {in }}$ & $\mathbf{W}$ & $\mathbf{X}$ & WAI & EC & ES & TI \\
\hline 1 & 46 & 146 & $16.9 \pm 3.8$ & $5.6 \pm 0.5$ & $1953.7 \pm 2.7$ & $53.9 \pm 0.5$ & $8.5 \pm 0.8$ \\
\hline 2 & 74 & 146 & $9.1 \pm 0.8$ & $4.4 \pm 0.2$ & $1616.2 \pm 1.9$ & $52.9 \pm 2.0$ & $10.5 \pm 0.4$ \\
\hline 3 & 46 & 174 & $12.0 \pm 0.7$ & $4.9 \pm 0.3$ & $1931.3 \pm 38.0$ & $55.0 \pm 1.0$ & $10.4 \pm 0.6$ \\
\hline 4 & 74 & 174 & $4.3 \pm 0.2$ & $4.4 \pm 0.4$ & $1593.4 \pm 21.0$ & $47.6 \pm 0.7$ & $6.2 \pm 0.1$ \\
\hline 5 & 40 & 160 & $17.8 \pm 1.4$ & $4.8 \pm 0.0$ & $2076.3 \pm 37.8$ & $53.9 \pm 1.5$ & $10.4 \pm 0.5$ \\
\hline 6 & 80 & 160 & $3.6 \pm 0.6$ & $4.0 \pm 0.7$ & $1490.1 \pm 28.8$ & $51.8 \pm 3.5$ & $8.1 \pm 0.6$ \\
\hline 7 & 60 & 140 & $6.6 \pm 1.0$ & $4.2 \pm 0.2$ & $1558.1 \pm 34.3$ & $50.1 \pm 2.2$ & $11.2 \pm 0.7$ \\
\hline 8 & 60 & 180 & $5.4 \pm 0.2$ & $3.8 \pm 0.5$ & $1518.0 \pm 0.3$ & $50.7 \pm 1.0$ & $6.5 \pm 0.5$ \\
\hline 9 & 60 & 160 & $5.2 \pm 0.3$ & $4.4 \pm 0.3$ & $1660.2 \pm 35.8$ & $53.1 \pm 2.7$ & $7.1 \pm 0.2$ \\
\hline 10 & 60 & 160 & $6.6 \pm 2.4$ & $4.2 \pm 0.3$ & $1680.6 \pm 24.3$ & $53.6 \pm 1.0$ & $6.2 \pm 0.0$ \\
\hline 11 & 60 & 160 & $5.5 \pm 0.2$ & $4.8 \pm 0.8$ & $1687.1 \pm 5.2$ & $54.5 \pm 0.3$ & $7.2 \pm 0.1$ \\
\hline \multicolumn{8}{|c|}{ Regression coefficients } \\
\hline \multicolumn{3}{|c|}{$\mathrm{b}_{0}$} & 6.4 & 4.5 & 1637.6 & 53.5 & 6.8 \\
\hline \multicolumn{3}{|c|}{$\mathrm{b}_{1}$} & -4.7 & -0.3 & -188.1 & -1.4 & -0.7 \\
\hline \multicolumn{3}{|c|}{$b_{11}$} & 2.8 & NS & 93.8 & NS & 1.2 \\
\hline \multicolumn{3}{|c|}{$\mathrm{b}_{2}$} & -1.4 & NS & NS & NS & -1.1 \\
\hline \multicolumn{3}{|c|}{$b_{22}$} & NS & NS & NS & -1.4 & 1.0 \\
\hline \multicolumn{3}{|c|}{$b_{12}$} & NS & NS & NS & -1.6 & -1.5 \\
\hline \multicolumn{3}{|c|}{$\mathrm{R}^{2}$} & 0.90 & 0.39 & 0.89 & 0.78 & 0.91 \\
\hline \multicolumn{3}{|c|}{$\mathrm{F}_{\mathrm{c}}$} & 21.8 & 5.7 & 34.1 & 8.5 & 10.7 \\
\hline \multicolumn{3}{|c|}{$F_{t}$} & 3.07 & 3.36 & 3.11 & 5.27 & 3.45 \\
\hline
\end{tabular}

NS is non-significant ( $\mathrm{p}>0.1)$

\subsection{Analytical methods}

\subsubsection{Physicochemical properties of the dried okara}

Moisture content was determined gravimetrically in triplicate in an oven at $105^{\circ} \mathrm{C}$ for $24 \mathrm{~h}^{[9]}$. The water absorption index (WAI, g absorbed water/g sample) analyses were carried out according to Seibel and Beléia ${ }^{[11]}$. The emulsifying capacity (EC, $\mathrm{mL}$ oil/g protein) was analyzed by continuous addition of oil to the sample until phase inversion of the emulsion, when the conductivity of the emulsion was below $10 \mu \mathrm{S}^{[12]}$. For emulsion stability (ES, \%), emulsion was prepared with okara and oil and placed in a $50 \mathrm{ml}$ graduated cylinder and stored at room temperature. The volume of the emulsified layer was observed until no variation was observed $^{[13]}$. The ES was calculated as the ratio of the emulsified layer and the total volume. The trypsin inhibitor activity (TIU/g solid) was determined according to the $\mathrm{AOCS}^{[14]}$, by 
extracting of the degreased sample with water for $30 \mathrm{~min}$, followed by buffer Tris $(0.05$ $\mathrm{mol} / \mathrm{L}, \mathrm{pH} 8.2$, containing $\mathrm{CaCl} 20.02 \mathrm{~mol} / \mathrm{L}$ ). One trypsin unit (TU) was arbitrarily defined as an increase of 0.01 absorbance units at $410 \mathrm{~nm}$ for $10 \mathrm{~mL}$ of a reactive mixture $(2 \mathrm{~mL}$ sample aliquot, $2 \mathrm{~mL}$ trypsin solution, $5 \mathrm{~mL}$ benzoyl-DL-arginine-4-nitroanilide hydrochloride substrate solution and $1 \mathrm{~mL}$ acetic acid solution). The trypsin inhibitor unit (TIU) was calculated as the difference in the absorbance between a standard test and the sample test.

\section{Results and Discussion}

\subsection{Spouted bed drying of okara}

The experimental data for moisture content (X), water absorption index (WAI), emulsifying capacity (EC), emulsion stability (ES) and trypsin inhibitor activity (TI) were fitted to Equation 1. The regression coefficients, F-values, $\mathrm{p}$-values and $\mathrm{R}^{2}$ are presented in Table 1 . After exclusion of non-significant terms $(p>0.1)$, the predictive models were tested for accuracy of fit by Anova. When the calculated F-value Fc was greater than the tabulated Fvalue $\mathrm{Ft}$, the variation was explained by the regression and not by the residues. Thus the regression was significant, and the model could be considered predictive. However, for the WAI, the $\mathrm{R}^{2}$ was low and the model was not predictive. Figure 1 shows the response surfaces generated by the proposed models.

As expected, higher temperature and air flow led to lower moisture content (Fig. 1a). Air flow played a significant role in fluid dynamic of particles. At higher air flow, there is a better contact between sample particles and air drying, improving the heat and mass transfer. Analyzing Figures 1(b) and 1(c), temperature had a significant and negative effect on emulsifying capacacity and emulsion stability, in which higher temperatures led to lower response values. These results were expected, since the okara proteins are thermosensitive, probably occurring their denaturation during the drying process. Several process parameters, such as $\mathrm{pH}$ and ionic strength, affect the functionality of proteins, especially temperature. Heat treatment has a great impact on the structure and, as consequence, on the emulsifying functionality of proteins ${ }^{[15]}$. Similarly to the emulsion properties, lower values of trypsin inhibitor activity were obtained at higher temperature and air flow (Fig.1d). Besides trypsin inhibitor is reversibly denatured by short heating to $80^{\circ} \mathrm{C}$ and irreversibly denatured by heating to $90^{\circ} \mathrm{C}^{[16]}$, the highest drying temperature used in the current work $\left(74^{\circ} \mathrm{C}\right)$ caused significant loses on its activity. 


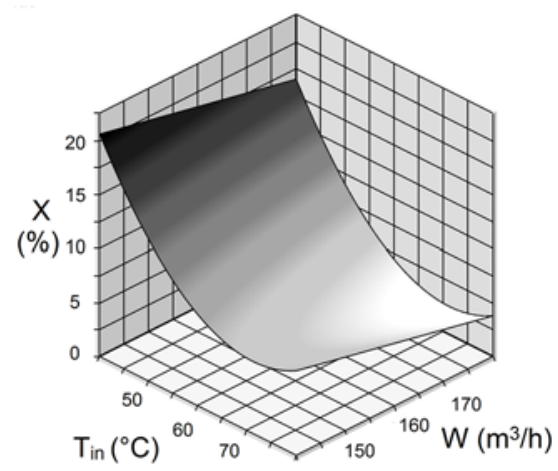

(a)

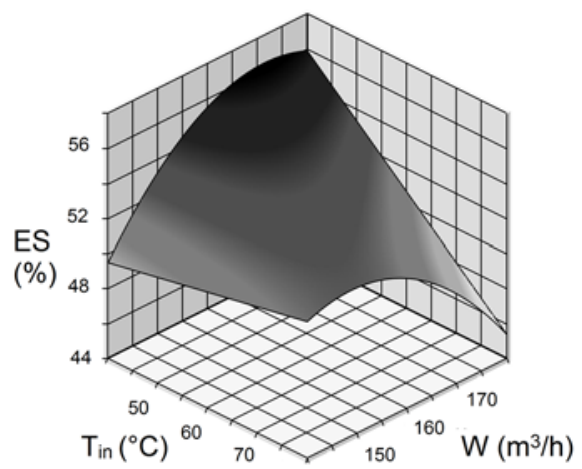

(c)

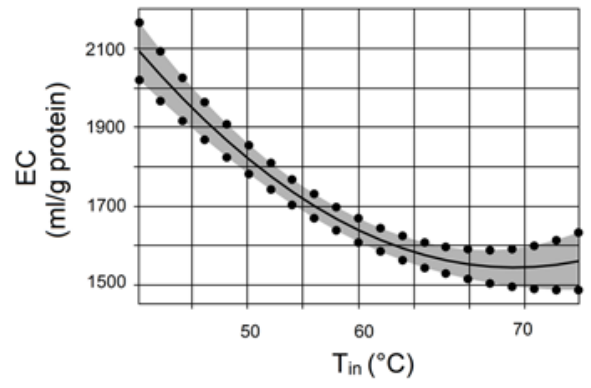

(b)

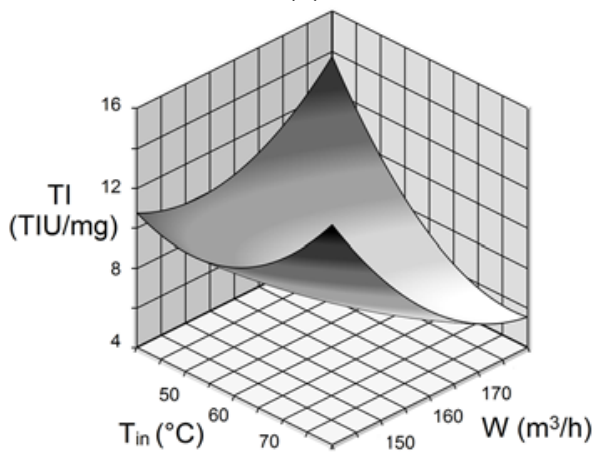

(d)

Fig. 1. Influence of independente variables on the responses: (a) moisture content; (b) emulsifying capacity; (c) emulsion stability and (d) trypsin inhibitors activity

\subsection{Characterization of the spouted bed dried okara obtained under the optimum condition}

Analyzying the responses surfaces (Fig. 1), the spouted bed drying of okara was optimized for maximum techno-functional properties and minimum moisture content and trypsin inhibitor activity. The optimal drying conditions were: $60^{\circ} \mathrm{C}$ and $180 \mathrm{~m}^{3} / \mathrm{h}$. Under optimal conditions, dried okara had a moisture content of $4.8 \pm 0.1 \%$ emulsifying capacity of $1754.3 \pm 18.0 \mathrm{ml} / \mathrm{g}$ protein, emulsion stability of $48.8 \pm 0.3 \%$, water absorption index of $4.7 \pm 0.52 \mathrm{~g} / \mathrm{g}$ sample and trypsin inhibitor activity of $6.7 \pm 0.1 \mathrm{TUI} / \mathrm{mg}$ sample.

In order to verify the influence of spouted bed drying on okara, these quality properties were also determined for freeze dried okara. As results, the emulsifying capacity and emulsion stability of freeze dried okara was respectively $2182.8 \pm 30.7 \mathrm{ml} / \mathrm{g}$ protein and $51.4 .8 \pm 0.4 \%$. On the other words, spouted bed drying caused a reduction of $19.6 \%$ and $5.1 \%$ on emulsion properties. On the other hand, an improvement on nutritional properties was observed, in 
which spouted bed drying reduced $27 \%$ of trypsin inhibitor activity of product $(9.3 \pm 0.3$ TUI/mg sample).

\section{Conclusions}

The spouted bed drying showed to be suitable to obtain dried okara with good technofunctional properties, mainly emulsifying capacity. In order to obtain maximum emulsion properties and minimum trypsin inhibitor activity, the optimal condition was proposed: $60^{\circ} \mathrm{C}$ and $180 \mathrm{~m}^{3} / \mathrm{h}$. There was a significant retention of emulsifying capacity and emulsion stability and reduction on trypsin inhibitor activity after spouted bed drying.

\section{Nomenclature}

$\begin{array}{lll}\text { EC } & \text { emulsifying capacity } & \mathrm{ml} \mathrm{g}^{-1} \text { protein } \\ \text { ES } & \text { emulsion stability } & \% \\ \text { TI } & \text { trypsin inhibitors activity } & \text { Trypsin inhibitor unit (TIU) } \mathrm{mg}^{-1} \text { sample } \\ \mathrm{T}_{\text {in }} & \text { Inlet air temperature } & { }^{\circ} \mathrm{C} \\ \mathrm{W} & \text { Air flow } & \mathrm{m}^{3} \mathrm{~h}^{-1} \\ \text { WAI } & \text { water absorption index } & \mathrm{g} \mathrm{g}^{-1} \text { sample } \\ \mathrm{X} & \text { moisture content } & \% \text { (wet basis) }\end{array}$

\section{Acknowledgements}

The authors acknowledge to FAEPEX/Unicamp (14759-17) for the financial support. Scafi, G. would like to thank São Paulo Research Foundation FAPESP for the scientific initiation scholarship (2016/11897-0). Kurozawa, L. is CNPq Research Fellow.

\section{References}

[1] Statista. The portal for statistic. Sales volume of soymilk worldwide in 2015 and 2018: 2018. https://www.statista.com/statistics/645662/soy-milk-sales-volume-worldwide (accessed Mar 19, 2018).

[2] Sbroggio, M.F.; Montilha, M.S.; Figueiredo, V.R.G.; Georgetti, S.R.; Kurozawa, L.E. Infuence of the degree of hydrolysis and type of enzyme on antioxidant activity of okara protein hydrolysate. Food Science and Technology 2016, 36(2), 375-381.

[3] Stanojevic, S.P.; Barac, M.B.; Pesic, M.B.; Vucelic-Radovic, B.V. Composition of proteins in okara as a byproduct in hydrothermal processing of soy milk. Journal of Agricultural and Food Chemistry 2012, 60(36), 9221-9228.

[4] Puechkamut, Y.; Panyathitipong, W. Characteristics of proteins from fresh and dried residues of soy milk production. Kasetsart Journal - Natural Science 2012, 46(5), 804811.

[5] Waliszewski, K.N.; Pardio, V.; Carreon, E. Physicochemical and sensory properties of corn tortillas made from nixtamalized corn flour fortified with spent soymilk residue 
(okara). Journal of Food Science 2002, 67(8), 3194-3197.

[6] Stanojevic, S.P.; Barac, M.B.; Pesic, M.B.; Zilic, S.M.; Kresovic, M.M.;VucelicRadovic, B.V. Mineral elements, lipoxygenase activity, and antioxidant capacity of okara as a byproduct in hydrothermal processing of soy milk. Journal of Agricultural and Food Chemistry 2014, 62(36), 9017-9023.

[7] Muliterno, M.M.; Rodrigues, D.; Lima, F.S.; Ida, E.I.; Kurozawa, L.E. Conversion/degradation of isoflavones and color alteration during drying of okara. LWT - Food Science and Technology 2017, 75, 512-519.

[8] Baú, T.R.; Ida, E.I. Soymilk processing with higher isoflavone aglycone content. Food Chemistry 2015, 183, 161-168.

[9] AOAC. Official Methods of Analysis, 19th ed. Association of Official Analytical Chemists International: Washington, D.C, 1995.

[10] Rodrigues M.I; Iemma, A.F. Experimental design and process optimization; CRC Press: Boca Raton, 2014.

[11] SEIBEL, N.F.; BELÉIA, A.D.P. The chemical characteristics and technological functionality of soybean based ingredients [Glycine Max (L.) Merrill]: carbohydrates and proteins. Brazilian Journal of Food Technolgy 2009, 12(2), 113-122.

[12] BARBIN, D.F.; NATSCH, A.; MÜLLER, K. Improvement of functional properties of rapeseed protein concentrates produced via alcoholic processes by thermal and mechanical treatments. Journal of Food Processing and Preservation 2011, 35(3), 369375.

[13] SURH, J.; DECKER, E.A.; McCLEMENTS D.J. Properties and stability of oil-in-water emulsions stabilized by fish gelatin. Food Hydrocolloids 2006, 20(3), 596-606.

[14] AOCS. American Oil Chemist's Society. Sampling and analysis of oilseed by-products. Trypsin Inhibitor Activity. AOCS Official Method Ba 12-75. Champaign, IL, USA, 2009.

[15] KEERATI-U-RAI, M.; CORREDIG, M. Heat-induced changes in oil-in-water emulsions stabilized with soy protein isolate. Food hydrocolloids 2009, 23(8), 21412148.

[16] Steiner, R.F.; Frattali, V. Purification and properties of soybean protein inhibitors of proteolytic enzymes. Journal of Agricultural and Food Chemistry 1969, 17(3), 513-518. 